\title{
ОСОБЛИВОСТІ ФОРМУВАННЯ ПАРЕНХІМАТОЗНО-СТРОМАЛЬНИХ ВЗАЄМОВІДНОСИН У МОРФОГЕНЕЗІ ОРГАНІВ ВИДІЛЬНОЇ І ДИХАЛЬНОЇ СИСТЕМ
}

\author{
๑О.М. Грабовий, Н.А. Колесова, О.О. Масіцька, В.І. Литвиненко, \\ Н.М. Сухарєва
}

\author{
Національний медичний університет імені О.О. Богомольця
}

РЕЗЮМЕ. Вивчено особливості формування епітеліомезенхімної взаємодії в пренатальному морфогенезі нирок і легень плодів білих щурів 14-го, 18-го і 20-го дня розвитку. Встановлено, що для перебігу морфогенетичних процесів в органі, у якому епітелій паренхіми і строма походять із різних зародкових листків, необхідна тісна контактна взаємодія клітинних шарів. У випадку органів, у яких клітини епітелію паренхіми і строми походять із одного зародкового листка, такий тісний контакт не є абсолютно обов'язковим.

КЛЮчОВІ СлОВА: сполучна тканина, епітелій, морфогенез, міжтканинні взаємовідносини, нирки, легені, ембріогенез.

Вступ. Формоутворювальна функція сполучної тканини, яка найбільш яскраво і інтенсивно проявляється в ембріональному періоді розвитку, здійснюється завдяки індуктивному впливу клітин, волокон і міжклітинної речовини на розмноження, міграцію та диференціювання епітеліальних клітин. Разом з тим, відбувається і зворотний вплив, який модулює стан строми, що формується. Ці міжтканинні взаємовідносини зберігаються і в постнатальному онтогенезі. Сполучна тканина впливає на стан інших тканин органів та визначає їхній морфофункціональний стан, підтримуючи гомеостаз організму. Властивості різних типів сполучної тканини (пухка і щільна), у тому числі і строми органів визначаються кількісними і якісними варіантами у взаємовідносинах між клітинами, волокнами і основною речовиною. Нормальне функціонування сполучної тканини забезпечується взаємозв'язком між всіма компонентами тканини. Від характеру взаємодії макромолекулярних вуглеводно-білкових комплексів колагену залежать структурно-функціональні властивості сполучної тканини, а їі міжклітинна речовина є інформаційною системою [1, 2].

Сучасні уявлення про сполучні тканини, 3 точки зору системного підходу, дозволяють розглядати їі як систему, що функціонує переважно в діапазоні між органним і клітинним рівнями організації. Особливості епітеліомезенхімних взаємовідносин, що закладаються в ранньому ембріогенезі, впливають на подальший морфогенез органа, а також на перебіг патологічних процесів, що розвиваються на фоні реактивних змін в його інтерстиції. Специфіка організації строми визначає не тільки їі здатність до підтримки власної організації, а й їі морфогенетичний вплив на інші тканинні компоненти органів.

Порушення стану сполучної тканини призводить до змін гомеостазу в організмі і виникнен- ня ряду патологічних процесів (запалення, склерозу, патологічної регенерації), у тому числі й хвороб сполучної тканини. Важко назвати патологічний процес або нозологічну форму, при якій зміни сполучної тканини не відігравали би тієї чи іншої ролі.

Метою дослідження - встановити особливості епітеліомезенхімних взаємовідносин у процесі пренатального формування нирок і легень в експерименті.

Матеріал і методи дослідження. Матеріалом слугували плоди білих безпородних щурів 14-го, 18-го і 20-го дня вагітності (ДВ), $\mathrm{n}=60$, отриманих від 10 самиць на кожен термін. Утримання та маніпуляції з тваринами проведені згідно з вимогами "Загальних етичних принципів експериментів на тваринах, ухвалених Першим національним конгресом з біоетики" (Київ, 2001). Тварин забивали із дотриманням правил евтаназії. Плоди виймали із рогів матки і плодових оболонок, фіксували в $10 \%$ розчині нейтрального формаліну. Далі за загальноприйнятими гістологічними методиками заливали у парафін, виготовляли зрізи товщиною 5-7 мкм і фарбували їх гематоксиліном і еозином та за ван Гізон.

Результати й обговорення. Легені і нирки $є$ органами, в утворенні яких мають місце подібні морфогенетичні процеси: епітеліальний зачаток вростає в компетентну мезенхіму і галузиться при взаємодії клітин епітелію та мезенхіми. Однак, якщо при формуванні легень епітелій має ектодермальне (ентодермальне) походження, то при формуванні нирок епітелій, як і строма, мезодермального походження. Ці особливості вихідного матеріалу для утворення епітелію накладають свій відбиток на епітеліомезенхімні відносини при формуванні органа в ембріогенезі, а останні, у свою чергу, впливають на міжтка- 
нинні взаємовідносини в дефінітивному органі $[3,4]$.

Відомо [5], що при формуванні легень вплив мезенхіми $€$ інструктивним, провідним, і вона $€$ індуктором галуження епітелію. Останній виступає компетентною тканиною, що відповідає на індукувальний вплив як клітин мезенхіми, так і міжклітинного матриксу, продукованого ними, зокрема, молекул колагену I і III типів.

У морфогенезі легень із зачатків двох різних ембріональних листків клітини мезенхіми вже на ранніх етапах ембріогенезу (14-й ДВ) конденсуються (згущуються, витягуються і концентруються) навколо епітеліальних зачатків щільними муфтами, що складаються із декількох шарів циркулярно розташованих витягнутих клітин, намічаючи майбутні м'язовий і фіброзний шари слизової оболонки стінки бронхів (у подальшому вони перетворюються на міоцити і фібробласти). Ці утворення оточує пухка мезенхіма спланхномезодермального походження, основу якої складають відросчасті клітини неправильної форми, розташовані без певної орієнтації.

У наступний період ембріогенезу (18-й ДВ) спостерігається подальша конденсація і диференціація клітин мезенхіми, які втрачають відростки і розташовуються концентричними тяжами навколо елементів бронхіального дерева, що формується. Епітеліальні вирости при цьому розділяються щілинами, які розщеплюють їхні відгалуження. Контроль над формуванням щілини виконують молекули колагену, які направлено продукуються і акумулюються в межах щілини орієнтованими певним чином мезенхімними клітинами. Перед народженням (20-й ДВ), незважаючи на те, що легені на цей час $€$ ще значно недорозвиненими, більшість клітин формує строму органа і недиференційованих клітин в легенях залишається мало.

При формуванні нирок зачаток сечоводу індукує метанефрогенну мезенхіму до перетворення в епітелій і нефрони. Цей крок слугує тригером каскаду реакцій в компетентній мезенхімі. Вона $є$ джерелом розвитку ниркових канальців (якщо вона індукована за рахунок контактної взаємодії з епітелієм) і ниркові клітини строми (якщо вона не індукована). Останні секретують позаклітинний матрикс, що складається переважно із фібронектину і колагену типів I і III, тоді як після індукції ці білки зникають і заміщуються базальною мембраною, що містить ламінін і колаген IV типу. Цитоскелет, характерний для мезенхімних клітин, заміщується притаманним для епітелію, після чого пухко розташовані клітини мезенхіми інтегруються в поляризований епітелій на базальній мембрані [5].
На відміну від легень, у випадку міжтканинних взаємовідносин у нирці, що формується, вплив мезенхіми на епітелій $є$ не інструктивним, а дозволяючим: зачатки епітеліальних виростів готові до росту і галуження, але вони потребують підтримки мезенхіми. Це проявляється у тому, що навколо епітеліальних трубочок у нирці не тільки на ранніх стадіях формування органа, але і особливо наприкінці ембріогенезу конденсується невелика кількість слабодиференційованих мезенхімоподібних клітин, які не утворюють навколо них концентричних шарів.

Із структурних елементів у нирках плодів 18го і 20-го ДВ розрізняють епітеліальні трубочки, що проростають із воріт нирки, утворюючи піраміду. Це збірні трубочки із широкими просвітами і світлими епітеліоцитами та прямі канальці нефронів з вузькими просвітами і темними епітеліоцитами. Тубули оточені слабодиференційованими мезенхімоподібними клітинами зірчастої форми. На цей час сформовані лише ниркові тільця і звивисті відділи юкстамедулярних нефронів. Однак звивисті канальці цих нефронів займають на зрізах незначну площу кіркової речовини на межі з мозковою, тобто про повний розвиток цих нефронів говорити рано. Кортикальні нефрони на цій стадії ембріогенезу тільки формуються, їхні капсули виражені нечітко, петлі слаборозвинуті, звивистих канальців у майбутньому кортексі дуже мало. Кортикальна зона займає вузьку смужку під капсулою нирки. Мезенхімні елементи концентруються навколо ниркових тілець одним-двома шарами витягнутих клітин, між ними знаходиться невелика кількість пухко розташованих недиференційованих клітин неправильної форми.

В інтерстиції мозкової речовини плодів 18го і 20-го ДВ спостерігається сітка мезенхімоподібних клітин зірчастої форми з переважною орієнтацією перпендикулярно до епітеліальних трубок. Ці клітини утворюють матрикс органа і не беруть безпосередньої участі в морфогенезі епітеліальних трубок та продукують міжклітинний матрикс з волокнами без чіткої орієнтації. Відмічена роль клітин інтерстицію у формуванні мікрооточення для канальців та судин, які вростають у мозкову речовину нирки [6], оскільки у подальшому онтогенезі в цю пухку мезенхіму будуть проростати новоутворені збірні трубочки, прямі відділи нефронів (петлі Генле) та перитубулярні капіляри.

у розвитку патології органів видільної і дихальної систем найбільш частим проявом морфологічних змін в інтерстиції легень і кортикальної зони нирок є посилення фібрилогенезу (склерозу, фіброзу і цирозу), що, з нашої точки 
Оәляди літератури, оригінальні дослідження, погляд на проблему, короткі повідомлення, замітки з практики зору, може бути наслідком виявлених особливостей пренатального морфогенезу сполучної тканини. У медулярній зоні нирок у пренатальному розвитку не створюються передумови для таких патологічних змін.

Висновки. 1. Порівняльний аналіз пренатального розвитку органів виділення і дихання підтвердив, що формоутворювальний вплив орієнтації і диференціювання мезенхімних клітин разом із продукованим ними позаклітинним матриксом детермінує характер росту і галуження епітеліальних структур органа.

2. Для перебігу морфогенетичних процесів в органі, у якому епітелій і мезенхіма походять із різних зародкових листків, і отже, мають різні поверхневі клітинні маркери, необхідна тісна

\section{ЛІТЕРАТУРА}

1. Серов В.В., Шехтер А.Б. Соединительная ткань. - М.: Медицина, 1981. - 312 с.

2.Hogan Brigid L.M. Morphogenesis // Cell. - 1999. V. 96, № 2. - P. 225-233.

3. Cardoso Wellington V. Lung morphogenesis revisited: Old facts, current ideas // Dev. Dyn. - 2000. - V. 219, № 2. - P. 121-130.

4. Demayo F., Minoo P., Plopper C.G., Schuger L., Shannon J., Torday J.S. Mesenchymal-epithelial interactions in lung development and repair // J.

контактна взаємодія клітинних шарів, тоді як у випадку органів, у яких клітини епітелію і мезенхіми походять із мезодерми і мають більш близькі маркери поверхонь, такий тісний контакт, очевидно, не є абсолютно обов'язковим.

3. Описані відмінності у морфогенезі епітеліального і сполучнотканинного компонентів життєво важливих органів можуть стати підґрунтям розвитку особливостей патологічних процесів у дефінітивних органах, що потребує спеціального вивчення.

Перспективи подальших досліджень. Дослідження в даному напрямку дозволять аналізувати причини вад ембріогенезу різних органів і систем та прогнозувати їх наслідки.

Histochem. Cytochem. - 2002. - V. 283, № 3. - P. L510L517.

5. Гилберт С. Биология развития / Пер. с англ. А.С. Гинзбург, Г.М. Игнатьевой Под ред. С.Г. Васецкого, Т.А. Детлаф - М.: Мир, 1993. - С. 135.

6. Баринов Е.Ф., Ткачова О.М., Сулаєва О.М. Міжнефронні взаємовідносини в онтогенезі: морфофункціональні механізми дозрівання нирки // Вісник морфології. - 1999. - № 2. - С. 178-181.

\section{PECULIARITIES OF PARENCHYMAL-STROMAL INTERACTIONS FORMATION IN THE MORPHOGENESIS OF RENAL AND RESPIRATORY SYSTEMS}

\section{(C).M. Hrabovy, N.A. Kolesova, O.O. Masitska, V.I. Lytvynenko, N.M. Sukhareva National Medical University by O.O. Bohomolets}

SUMMARY. Mesenchymal-epithelial interactions peculiarities of prenatal morphogenesis of albino rat fetus kidney and lung $(14,18,20$ days of pregnancy) were studied. There were used histological methods. It was revealed that there is a close interaction between tissue layers during the morphogenetic process in lung, but in kidney there is not so close interrelationship between mesenchimal and epithelial cells.

KEY WORDS: connective tissue, epithelium, morphogenesis, intertissular interactions, kidneys, lungs, embryogenesis. 